\title{
Middle East Chronic Water Problems: Solution Prospects
}

\author{
Hussein Al-Rimmawi ${ }^{1}$ \\ ${ }^{1}$ Geography Department, Birzeit University, Palestine \\ Correspondence: Hussein Al-Rimmawi, Geography Department, Birzeit University, Palestine. E-mail: \\ hrimmawi@birzeit.edu
}

Received: March 6, 2012 Accepted: March 20, 2012 Online Published: May 3, 2012

doi:10.5539/eer.v2n1p28

URL: http://dx.doi.org/10.5539/eer.v2n1p28

\begin{abstract}
Water shortages have been for a long time a serious problem in the Middle East as well as other parts of the world. The large and arid land of the Middle East has also been dependant on water which is provided by few rivers. This issue has been tackled by researchers, orientalists and exploration associations (Palestine Exploration Fund 1882, and Oliphant, 1880). The aim of this paper is to tackle ways of managing and solving chromic water shortages and hydropolitical tensions in the Middle East. None of the Middle Eastern Countries enjoys water surplus with exception of Turkey. Fortunately, some Arab countries such as Saudi Arabia, Kuwait, Qatar, United Arab Emirates and Oman which suffers from water shortages enjoys fuel surplus. These countries are trying to solve their water shortages by using underground water and heavily investing in water desalination. Other countries like Palestine, Lebanon, Syria and Iraq are losing their grip on their national water as a result of sever and perpetuated conflicts which have never ended since the First World War. In terms of technological progress Middle Eastern countries are also differentiated. In this respect, Turkey managed to develop itself and upgrade its social and economic conditions, but most of Arab countries are lacking behind. All of Middle Eastern countries enjoy and share rich cultural heritages related to water management and consumption. Such a richness will help to upgrade peoples' awareness regarding water consumptions and uses in different economic sectors.

Middle Eastern countries suffer from physical water scarcity and the neighboring regions in Africa, Europe and Latin America suffers from economic water scarcity. In addition the regions are of little or no water scarcity lie in Northern Eurasia and Antarctica. As a result of these differences, this paper will suggest ways in which concerned countries and professional organizations may take part in bridging the gap between such physical and economic water scarcities. A projected model of cooperation between Middle Eastern countries in terms of natural resources, cultural, economic, and social enterprises needs to be developed. In addition, International community has to take part in introducing solutions to conflicts of Arabs and Israel, Iraq, Iran, Cyprus, Afghanistan, and Yemen.
\end{abstract}

Keywords: Middle East, water scarcity, future solutions, permanent peace

\section{Introduction}

Most countries of the Middle East regardless of their locations are rapidly facing increasing water scarcity which may be aggravated the effects of climate change on all aspects of water use. In fact some countries a per capita share of available water has dropped to 170 cubic meters per year. This fact is a sad one since it is below the internationally recognized water scarcity standard of 1000 cubic meters. Less per capita share means less food production, slow in economic development and social instability of the entire Middle Eastern countries (Haskins, Dold \& Clarke, 2010). Rapid increases of Middle Eastern population and food shortages are the main driving forces which determine the rising needs for fresh water. Countries of the Middle East have been growing in their dependence of food imports and this is accompanied by rising of fuel prices since 1970's and population increase. Throughout the period from 1970 to 2000 food imports bill for the region rose 17-fold with an average increment of $10 \%$ per year (Hakimian, 2003; Molden, 2007; Hemson et al., 2008). In fact the Middle East and North African countries suffer from sever water scarcity. This region is the home of $6.3 \%$ of world's population but it contains only $1.4 \%$ of the world's renewable fresh water.

As a result there has been many attempts to address the subject of this region's water availability. Allan (1997) reports that the Middle East as a region ran out of water in 1970's and it was difficult to meet the water needs of household, food production, industrial and municipal. Food imports of Middle Eastern countries are rising and 
may be considered the major indicators of water deficit of an economy since food is the dominant consumptive use of water. Furthermore, the uses of water in agriculture sector exceeds by ten times uses of water by industrial and municipal sectors combined.

\section{Population versus Water Availability}

In fact the Middle East is very much in need of water policies and management priorities since freshwater is affected by growth of population and uses of water per head. Table 1 illustrates the annual Renewable Freshwater Available in MENA and Arab countries in 2000 and 2030. Index numbers of this table and Figure 2 illustrate that while population are sharply increasing the per capita renewable fresh water are decreasing. The situation is getting worse in Arab countries which are rich of oil resources. In fact Figure 1 and Table 1 show that all of Middle Eastern countries are facing water scarcity. This is may be an alarm to everybody in the region especially those of decision makers and academics within and outside of the region. Furthermore, index numbers of Figure 2 illustrates that there is a big gap between annual renewable freshwater available and population in MENA and Arab Countries: 2000 - 2030. Such a gap may lead to severe socio-economic consequences. As a result more illegal immigrants may be pushed toward developed continents such as Europe. In addition the failure of economic development plans already led to put down some regimes in the regions such as Tunisia, Libya, and Egypt. Other regimes are facing serious problems staying alive such as Syria and Yemen. People of other countries in the region may follow apace.

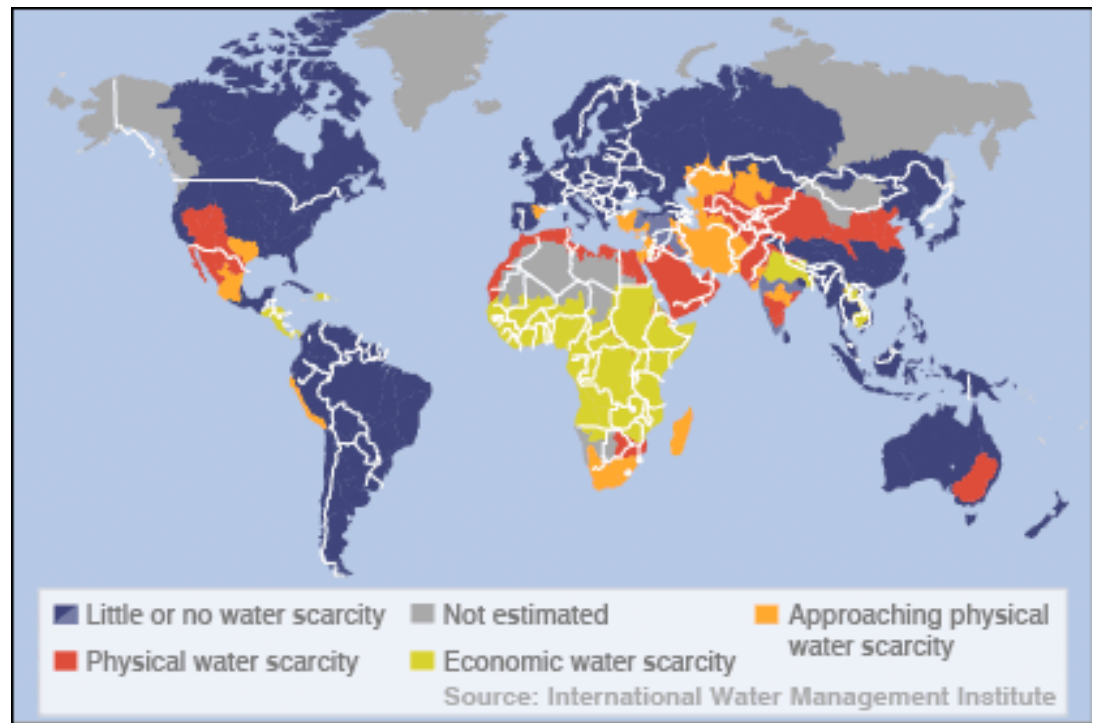

Figure 1. Areas of fast approaching economic and physical water scarcity (Source: Palaniappan, 2008)

Table 1. Annual renewable freshwater available and population in MENA and Arab countries in 2000, and 2030 (Projected)

\begin{tabular}{ccccccc}
\hline & $\begin{array}{c}\text { Per capita annual renewable } \\
\text { fresh water }\left(\mathrm{m}^{3}\right)\end{array}$ & & & Population (millions) \\
\hline Country & 2001 & 2025 & $\begin{array}{c}\text { Index numbers } \\
2001-2025\end{array}$ & 2001 & 2025 & $\begin{array}{c}\text { Index numbers } \\
2001-2025\end{array}$ \\
\hline MENA Countries & 1640 & 1113 & $68 \%$ & 385.6 & 568 & $147 \%$ \\
Algeria & 462 & 331 & $72 \%$ & 31 & 43.2 & $139 \%$ \\
Bahrain & 140 & 97 & $69 \%$ & 0.7 & 1.0 & $142 \%$ \\
Egypt & 1243 & 903 & $73 \%$ & 69.8 & 96.2 & $139 \%$ \\
Iran & 2079 & 1555 & $75 \%$ & 66.1 & 88.4 & $134 \%$ \\
Iraq & 4087 & 2392 & $58 \%$ & 23.6 & 40.3 & $171 \%$ \\
Israel & 342 & 247 & 72 & 6.4 & 8.9 & $139 \%$ \\
Jordan & 174 & 103 & $59 \%$ & 5.2 & 8.7 & $167 \%$ \\
Kuwait & 9 & 5 & $56 \%$ & 2.3 & 4.2 & $182 \%$
\end{tabular}




\begin{tabular}{ccccccc} 
Lebanon & 1120 & 896 & $80 \%$ & 4.3 & 5.4 & $126 \%$ \\
Libya & 114 & 72 & $63 \%$ & 5.2 & 8.3 & $160 \%$ \\
Morocco & 1027 & 741 & $72 \%$ & 29.2 & 40.5 & $139 \%$ \\
Oman & 416 & 206 & $50 \%$ & 2.4 & 4.9 & $204 \%$ \\
Qatar & 170 & 129 & $76 \%$ & 0.6 & 0.8 & $133 \%$ \\
Saudi Arabia & 114 & 59 & $52 \%$ & 21.1 & 40.9 & $194 \%$ \\
Sudan & $4953(2000)^{*}$ & $2929(2030)^{*}$ & $59 \%$ & $31.0(2000)^{*}$ & $52.5(2030)^{*}$ & $169 \%$ \\
Syria & 2700 & 1701 & $63 \%$ & 17.1 & 27.1 & $158 \%$ \\
Tunisia & 422 & 327 & $77 \%$ & 9.7 & 12.5 & $129 \%$ \\
UAE & 60 & 44 & $73 \%$ & 3.3 & 4.5 & $136 \%$ \\
Yemen & 228 & 103 & $45 \%$ & 18 & 39.6 & $220 \%$ \\
Turkey & 3029 & 2356 & $78 \%$ & 66.3 & 85.2 & $129 \%$ \\
\hline
\end{tabular}

Source: Roudi-Fahimi, Creel, and De Souza. (2002).

*Economic and Social Commission for Western Asia, 2003

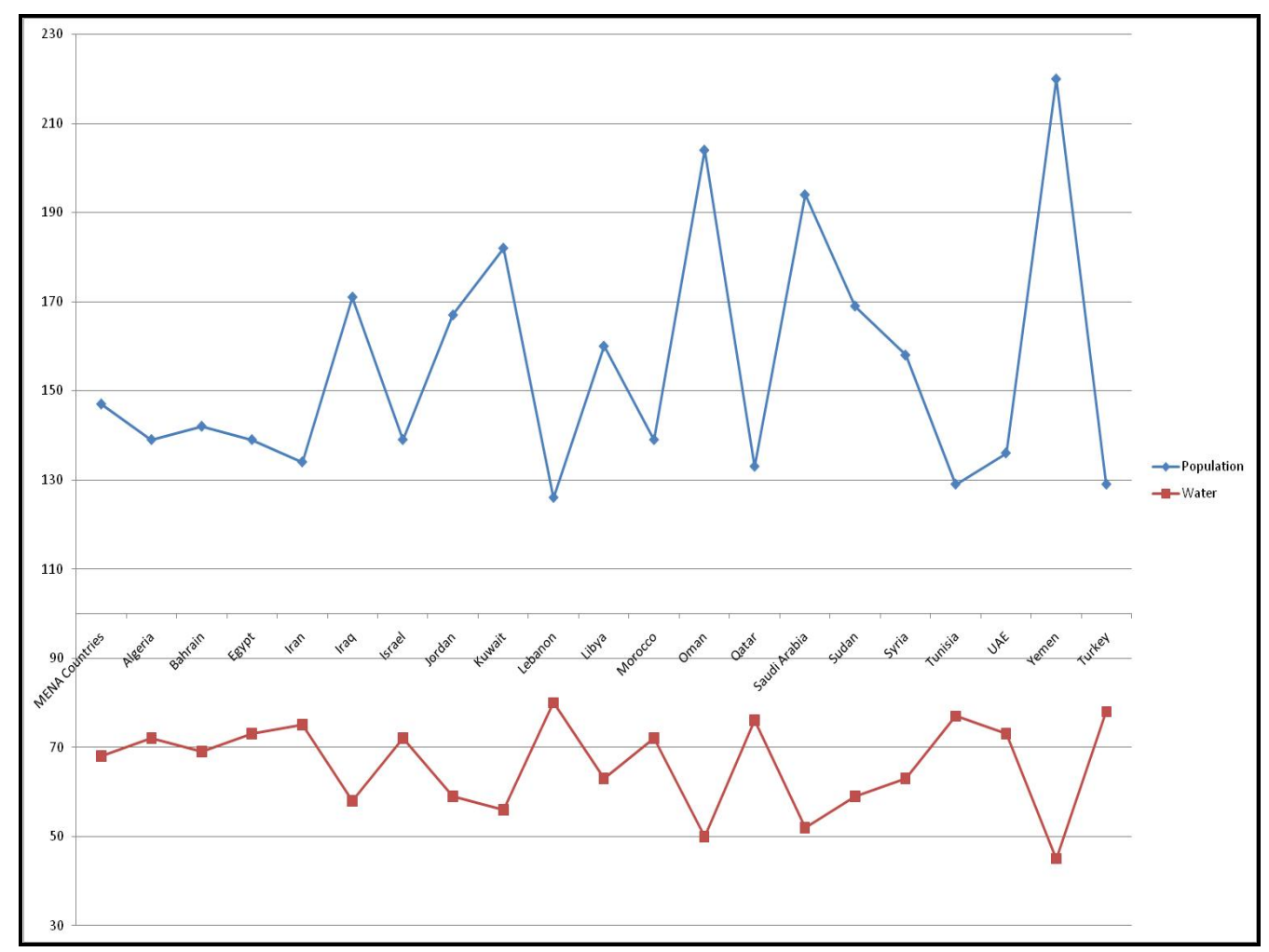

Figure 2. Index numbers of annual renewable freshwater available and population in MENA and Arab countries: 2000-2030 (Projected)

There are several causes of water crises in the Middle East such as rainfall variability in its countries and has its impact on agriculture, vegetation, grazing and underground water. Another cause is the population increase. It is expected that Middle Eastern countries will increase by 183 million people for the period between 2001 and 2025. Such a high increase will put more pressure on water resources (Roud-Fahimi, Creel \& De Souza, 2002). Thirdly, water resources are shared by various countries which varies in their visions and policies toward managing and uses of available water. Fourthly, economic growth and improvement of life conditions is expected to lead toward more consumption of water. Furthermore, unilateral diversion and management of water resources resulted in conflicts between neighboring countries such as the Arab Israeli conflict. Finally, absence and weakness of managing and using of technology in different uses of water (Khinsee, 2005). 


\section{Solving Water Scarcity}

Many Middle Eastern countries have increasingly been adopting new strategies for balancing their water shortages. These countries are trying to locate, develop, and manage new sources despite their limited financial resources. Many Middle Eastern countries are trying the desalination, treat, and reuse of waste-water while continuing to use older methods such as qanats and rainwater harvesting from roofs, cisterns, diverts runoff into ponds and reservoirs. A second method is the sequential water use which involves capturing and treating water that has been used in one sector so that it can be directed to other uses, such as the uses of water for household and, then for industry and later for agriculture. Desalination is third method which is being used in Arab Gulf States. A fourth method, is trading water from one region to another by shipping or pipeline despite its impact on ecosystems and hydrology (Roudi-Fahimi, Creel \& De Souza, 2002; Wolf, 1996).

Many studies have been carried out dealing with water needs and projects in the Middle East such as Al-Rubay'e (2002), Kally (1991), Kally and Fishelson (1993) and Shaded (1999). It has been reported that strategies for managing water demands include several steps:

1- Water reallocation to satisfy needs of urban populations but this can harm food security and livelihood of farmers.

2- Less Water-Intensive Crops: MENA countries may switch to less water-dependent crops and sell their products in order to import the needed cereals. By this way countries may conserve water. However, certain countries may think that producing own cereals is a matter of national pride. In fact, some Arab Countries are investing their financial surplus in cereal production. The State of Qatar is investing its financial resources in rice and Wheat production in Sudan (Muhamad, 2011).

3- Efficient Technologies: It has been proved that using drip irrigation reduces water use between 30 and 70 percent and increase crop yields by 20 and 90 percent if compared by traditional methods of irrigation. For example $25 \%$ reduction in agricultural use (if local political sensitivity controlled) doubles the water available to other sectors. Other methods are the uses of crops that suite to water-scarce regions, and the uses of drip irrigations

4- Distribution Efficiencies which includes repairing leaking distribution systems and expanding sewer pipes, metering water connections and rationing water use.

5- Public Education and Involving Local Communities to accept new water systems.

6- Countries may adopt variety of ways to conserve water including the influence of religious leaders in churches and mosques to give speeches regarding water conservation.

7- Economic Consideration: At present many countries are imposing accumulated water tariffs on consumers.

8- Water Recycle: Pricing policies result in lowering industrial water consumption. For example a steel mill in Jordan lowered its water demand from 450 cubic meters to 20 cubic meters when its cooling water was recycled.

9- Institutional Reforms: Reforms may be introduced to facilitate public, private and nongovernmental participation of water management and consumption.

10- Slowing Population Growth: Frameworks for slowing population growth and improving people's lives may be introduced and this is has been done by the United Nations International conference on Population and Development (Roudi-Fahimi, Creel, \& De Souza, 2002; Economic and Social Commission for Western Asia, 2003).

In fact, the First International Conference and Workshops on iceberg utilization for fresh water production, weather modification and other applications was held at Iowa State University, Iowa, USA, 2-6 October, 1977 in order to review the possibilities of utilizing Antarctica's ice as a source of fresh water to the arid regions such as Arabian Peninsula. Antarctica holds $80 \%$ of world's ice and amounts to nearly three quarters of the Earth's fresh water (Manley, 1979). Prince Mohammed Al-Faisal of Saudi Arabia considered the Antarctica icebergs as a source of freshwater to Saudi Arabia. Economic projections showed that operating costs of water from icebergs delivered to Saudi Arabia compares favorably with water produced by desalination (Al-Faisal, 1977).

Previous points have addressed ways to solve freshwater shortages within the MENA countries in terms of rain, rivers, lakes, springs and ground water reserves. But it did not go further to neighboring regions (A'ib, 2009; Lewis, 2000) which have surplus of water such as Russia, North and South Pools. Table 2 illustrates examples of many countries in the Middle East that have suggested projects in order to secure the needed water. 
Table 2. Main water projects in the Middle East

\begin{tabular}{lll}
\hline Country to Export Water & Country to Import Water & Method \\
\hline Iraq & Jordan, Kuwait, Qatar, Saudi Arabia, United Arab Emirates & Pipe Lines \\
Zaire & Saudi Arabia & Pipe Lines \\
Egypt & Saudi Arabia & Pipe lines \\
Sudan & Saudi Arabia & Pipe Lines \\
Pakistan & Saudi Arabia & Sea \\
Pakistan & United Arab Emirates & Pipe Lines \\
Malaysia & Arab Gulf States & Sea \\
Iran & Kuwait and Qatar & Pipe Lines \\
Turkey & Jordan and Arab Gulf States & Pipe Lines \\
Egypt & Israel & Pipe Lines \\
\hline
\end{tabular}

Source: Al-Rubay'e, 2002.

Arab Gulf States are hesitant of importing freshwater from other countries because of the following of their concerns of future political upheavals may which result in halting the transfer of water to their lands. In addition such countries are concerned that pipe lines and seas may witness terrorist attacks which may stop the flow of water between exporting and importing countries.

In fact technologies may, at present, facilitate transporting water from these regions which contains $90 \%$ of fresh water. For example water could be transported from areas of water surplus. But first, if Middle East conflicts are solved such as the Arab Israeli conflict and mutual understanding between riparian countries should be reached (Rababa', 2002; Isa, 1991). Furthermore, fresh water may be imported from Antarctica, northern parts of Russia, equator states of Asia, and Amazon basin by ships, or by pipelines. Since it is within geographic proximity, water may be imported from equator in Africa by pipelines or by ships since these areas receive 1600 billion cubic meters annually. Figure 3 shows projected routes of water Transfer. Because of their failure of being able to solve water problems within the region, concerned countries are trying to secure needed water from outside regions of water surplus such as North America, Russia, Asia and Africa.

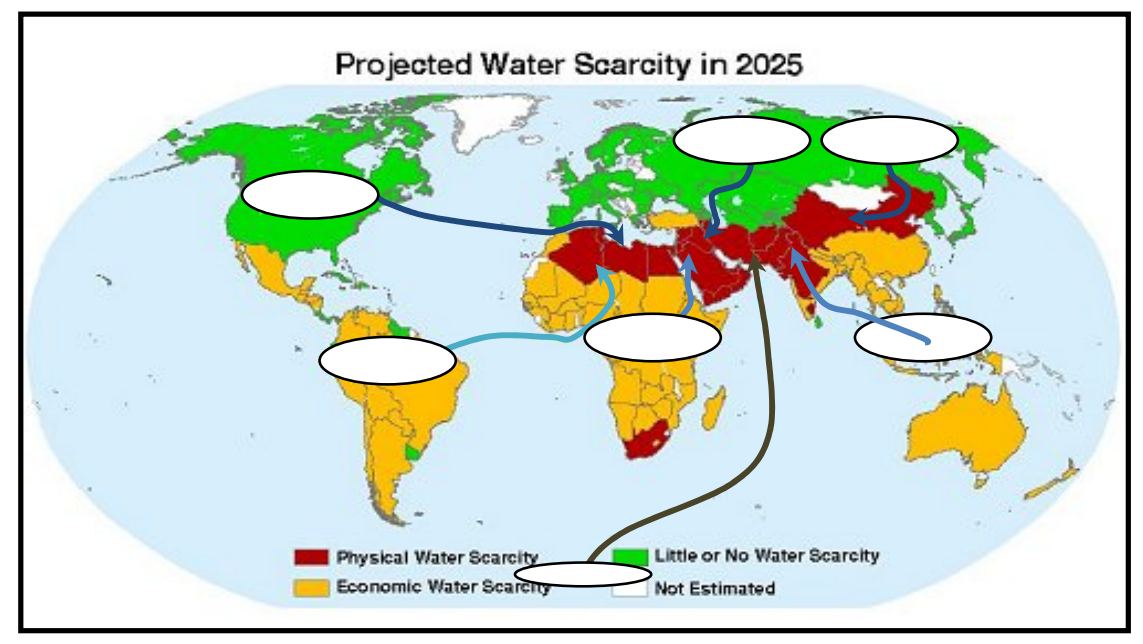

Figure 3. Projected Routes of Water Transfer

Source: http://mappery.com/Projected-Global-Water-Scarcity-2025-World-Map 


\section{Conclusion}

Middle Eastern countries are heading toward severe shortages of fresh water if their population kept the pace of increasing. Fresh water for various uses will become less and less. In fact water scarcity will be worse and worse especially if governments and international donors stands weak in front of this severe regional problem. If the situation persists, domestic water services will be collapsed for hundreds of millions of people. As a result, food production per capita will decline. Conflicts between the states of this strategic region, over fresh water may be aggravated and foods prices will increase sharply (Wolf, 1996). Scarcity of water will lead toward excess underground water extraction and speeds the recession of ecological systems and lowers water quality (Rosegrant, Cai \& Cline, 2002). This is exactly what is happening in Palestinian Gaza Strip. The author believes that only compiled full corporation between its countries forces itself for generation to come. In fact cooperation between countries of water scarcity and others of little or no water scarcity may be reached to help solving water shortages. Governments, professionals and other civic society organizations may take their part in putting the most efficient ways to transfer water from exporting countries toward importing countries. In addition, they may help in putting projects of low costs such as solar and wind energy which may be used in transporting fresh water. Finally, water desalination is another option, despite its high costs, governments may take into their considerations.

\section{References}

A'ib, H. (2009). Water in the Middle East: Political Geography of Resources and Conflicts. Cairo: General Egyptian Book Association.

Al-Abbasi, R. T. (2010). Water Crises in Arabian Gulf and Proposed Alternatives. Retrieved from http://pulpit.awatanvoice.com/content-95154.html (April 19, 2010)

Al-Faisal, M. (1977). Water Supply and Weather Modifications Through the Use of Transported Icebergs from Antarctic. Desalination, 20(103), 415-423. http://dx.doi.org/10.1016/S0011-9164(00)88239-9

Alkawaz, Ahmad. (1993). Water Crises in the Arab World. Kuwait: Arab Planning Institute. (in Arabic)

Allan, T. (1997). Virtual Water: A Long Term Solution for Water Short Middle Eastern Ecinomies? Paper presented at the British Association Festival of Science, Roger Stevens Lecture Theatre, University of Leeds, Water and Development Session, TUE. 51, 14.45, 9 September.

Al-Rubay'e, S. (2002). Water projects in the Middle East. Damascus: Dar Al-Hasad for publication, printing and Distribution. (in Arabic)

Al-Rubay'e, S. (2009). Suggestions to End Water Crises with Turkey. Al-Hewar Al-Mutamaden. No. 2742. Retrieved from www.alhewar.org.deat/showart.asp?aid=181630 (March 25, 2010)

Brans, Edward et al. (1997). The Scarcity of Water: Emerging Legal and Policy Responses. London: Kluwer Law International.

Daibes, F. (2003). Water in Palestine: Problems-Politics-Prospects. Jerusalem: Palestinian Academic Society for the Study of International Affairs.

Demashqiyyah, A. (1994). Water Crises and Conflicts in the Arab Area. Damascus: Al-Ahali for Printing, Publication and Distribution.

Economic and Social Commission for Western Asia. (2003). Population and Development Report: First Issue: Water Scarcity in the Arab World. New York: United Nations.

Elmusa, S. (1997). Water Conflict. Washington D.C.: Institute for Palestine Studies.

Hakimian, H. (2003). Water Scarcity and Food Imports: An Empirical Investigation of the 'Virtual Water' Hypothesis in the MENA Region. $10^{\text {th }}$ Annual Conference of the Economic Research Forum for the Arab Countries, Turkey and Iran, 16-18, December, Morocco.

Hasan, Y. (2010). The Coming War. Retrieved from www.ikhwanonline.com/Article.asp?.ArtID=54542\&Sec.Id $=344($ March 23, 2010)

Haskins, J. et al. (2010). Scientists Unite to Combat Water Scarcity; Solutions Yield More crop per drop in Drylands. Retrieved from www.eurekalert.org/pub_releases/2010-020210.php (March 15, 2010)

Hemson, D. et al. (2008). Poverty and Water: Explorations of the Reciprocal Relationship. Lindon \& New York: Zed Books. 
Isa, N. (1991). Water Problem in the Middle East, Part 2. Beirut: Strategic Center for Research and Documentation. (in Arabic)

Kally, E. (1991). Water and Peace: An Israeli View Point. Beirut: Organization of Palestinian Studies. Translated to Arabic by Randa Haidar Shararah. (in Arabic)

Kally, E., \& Fishelson, G. (1993). Water and peace: Water Resources and the Arab-Israeli Peace process. Westport, Conn: Praeger.

Kewis, B. (2000). Predictions: the future of the Middle East. Beirut: Riyad Rayis Company for Books and Publication. Translated to Arabic.

Khalouf, M. (2010). Project of Water Transfer from Coast to Damascus in its Final feasibility Study. Retrieved from www.lifenet-sy.com/yh/tl3594html (March 10, 2010)

Khinsee, B. (2005). Present Water Condition in most Middle Eastern Countries. Retrieved from www.kurdistanabinxete.com/Gotar/Bewarxense/Evliortanavin.html (March 30, 2010)

Kuwait News Agency. (2010). China Decides to Transfer Water from South to North with a cost 60 Billion Dollars. Retrieved from www.kuna.net.kw/NewsAgenciesPublicSite/Article (March 20, 2010)

Manley, G. (1979). Review: Water from Antarctica: Review. The Geographical Journal, 145(2), 305-307. http://dx.doi.org/10.2307/634398

Molden, D. (Editor). (2007). Water for Food Water for Life: A comprehensive Assessment of Water Management in Agriculture. UK \& USA: Earthscan.

Muhamad, A. (2011). Qatar intends toward investments in agriculture in Region. Retrieved from http://www.raya.com/site/topics/printArticle.asp?cu_no $=2 \& i t e m \_n o=609428 \& v e r s i o n=1 \&$ template_id $=35$ \&parent_id=34 (December 12, 2011)

Oliphant, L. (1880). The Land of Gilead. London: William Blackwood and Sons.

Palaniappan, M. (2008). Peak Water. Utah American Planning Association Annual Conference, Salt Lake City, Utah

Rabab'a, G. I. (2002). Water Dilemma in the Middle East. Abu Dhabi: United Emirates Center for Strategic Research and Studies. (in Arabic)

Rosegrant, M. et al. (2002). Global Water Outlook to 2025: Averting an Impending Crises. Washington D.C., USA: International Food Policy Research Institute.

Roudi-Fahimi, C., \& De Souza. (2002). Finding the Balance: Population and Water Scarcity in the Middle East and North Africa. Population Reference Bureau, Washington D. C. Retrieved from www.prb.org (March 17, 2010)

Saunders, T. (1882). Map of Western Palestine. London: Committee of the Palestine Exploration Fund.

Shadeed, O. (1999). Water and Palestinian Security. Amman, Jordan: Dar Majdalawi for Publication and Distribution. (in Arabic)

Wolf, A. (1996). Middle East Water Conflicts and Directions for Conflict Resolution. Washington D.C. USA: International Food Policy Research Institute. 